\title{
BLOOD GROUPS, ANTHROPOLOGY AND LANGUAGE IN WALES AND THE WESTERN COUNTRIES
}

\author{
A. E. MOURANT \\ Blood Group Reference Laboratory (Medical Research Council), Lister Institute \\ for Preventive Medicine, London, S.W. I \\ and \\ I. MORGAN WATKIN * \\ John Innes Institution and National Blood Transfusion Service, Wales
}

\section{INTRODUCTION}

Received

OuR knowledge of the topographical distribution of the $A B O$ groups in Europe is sufficient to enable us to draw a clear picture which is unlikely to be altered fundamentally by more detailed investigations carried out in the future. The distribution of the $R h$ groups is much less completely determined. On the whole the observations on these two blood group systems are readily reconciled with one another but certain apparent discrepancies need further investigation.

The object of this paper is to survey the available data as to the $A B O$ and $R h$ blood group frequencies of the peoples of Western Europe, especially Wales, and of North Africa, and to suggest certain correlations between the distribution of the blood groups and the findings of historians, prehistorians and philologists.

The survey of the blood groups of the area, apart from Wales, is the work of A. E. Mourant. The entire study of the people of Wales and their relations with other populations and the conclusions are the work of I. Morgan Watkin.

\section{BLOOD GROUPS}

(i) $A B O$

General.-Europe can broadly be divided into three areas on the basis of the frequencies of the $A B O$ blood groups. Most of Western Europe shows a high frequency of group $A$ (as compared with the rest of the world) with medium $O$ and rather low $B$, the percentage gene frequencies being of the order : $A=30 ; \mathrm{B}=5 ; O=65$. East of the Baltic and Adriatic seas and of a line running through Central Germany there is a rise of $B$, mainly at the expense of $O$, and this rise apparently continues steadily to give very high $B$ levels in Central Asia and India.

West of the main area of high $A$, and at a number of other places on the periphery of Europe, we find very high $O$ levels with $B$

* Working with the assistance of a grant from the Nuffield Foundation. 
somewhat higher than in the high $A$ area. These remarks apply to Iceland, Scotland and Ireland, to much of Wales and, to a less marked degree, to Northern England.

The $A, B$ and $O$ isogenes of the two western zones are shown in figs. I-3 which are based on work described in this paper, on the compilations of Boyd (1939) and de Hoyos Sainz (1947), on an unpublished survey of the north of Scotland by $\mathrm{Dr} H$. J. R. Kirkpatrick, and on a number of papers on individual countries, cited in the list of references.

Wales.-The inhabitants of Caernarvonshire, Denbighshire and Flint, particularly those bearing North Welsh surnames, have very high $O$ frequencies. The figures given by Fraser Roberts correspond to percentage gene frequencies of $A=19 \cdot 1 ; B=5{ }^{\circ} \circ ; O=76 \cdot 0$. vide figs. $4-6 . *$

In Merioneth along the coastal plain of Ardudwy which stretches from Barmouth to a point slightly north of Harlech, and in the small peninsula around Penrhyndeudraeth, the natives display a similar character. In the mountainous region of the Rhinog and Arennig to the east, however, the $O$ frequency drops slightly and, in places, appreciably. Southwards from Barmouth, along the shores of Cardigan Bay through Towyn, Aberdovey and Aberystwyth, the $O$ levels are still high.

There may be an island of high $O$ on and around the Prescelly mountains in Pembroke but further data are needed in order to establish this.

In South Wales the Black Mountains of Brecknock and the adjacent Wye Valley stand out among their neighbours-the Herefordshire plain to the east and the Radnor Forest to the north-in harbouring a population of high $O$ value.

A few small mountain areas show high $B$ frequencies which are almost unique in Western Europe. They are discussed in detail in the section on anthropometry.

Speaking very generally, one might say that in South Wales only one or two regions display really high $O$ levels, whereas in North Wales this feature is exhibited by the inhabitants of both hill and dale. This suggests that North Wales has not been subjected to the human migrations which have affected the southern half of the country.

* Note.-In compiling the genc frequency maps of Wales and the Marches, use was made of the Fraser Roberts (1942) figures for Caernarvonshire, Denbighshire and Flintshire and of additional data relating to these counties which is now available. The frequencies in the remaining areas arc based entirely on unpublished data and relate to approx. 20,000 persons. Gloucestershire and Somerset (Fraser Roberts, $194^{8}$ ) have been included for comparative purposes.

The coalfields and the principal cities of South Wales have been excluded as their present-day inhabitants are not representative of the original populations. Glamorganshire, e.g. receivcd betwcen I $86 \mathrm{I}$ and I9II 400,000 immigrants from outside the county, more than half of whom hailed from beyond Wales. Monmouthshire received an even greater proportion of English immigrants. 
Two regions supposed to be racially allied to Wales are Cornwall and Brittany. The former does not, however, differ significantly

\section{NORTH WEST EUROPE}

DISTRIBUTION OF BLOOD GROUP GENE A

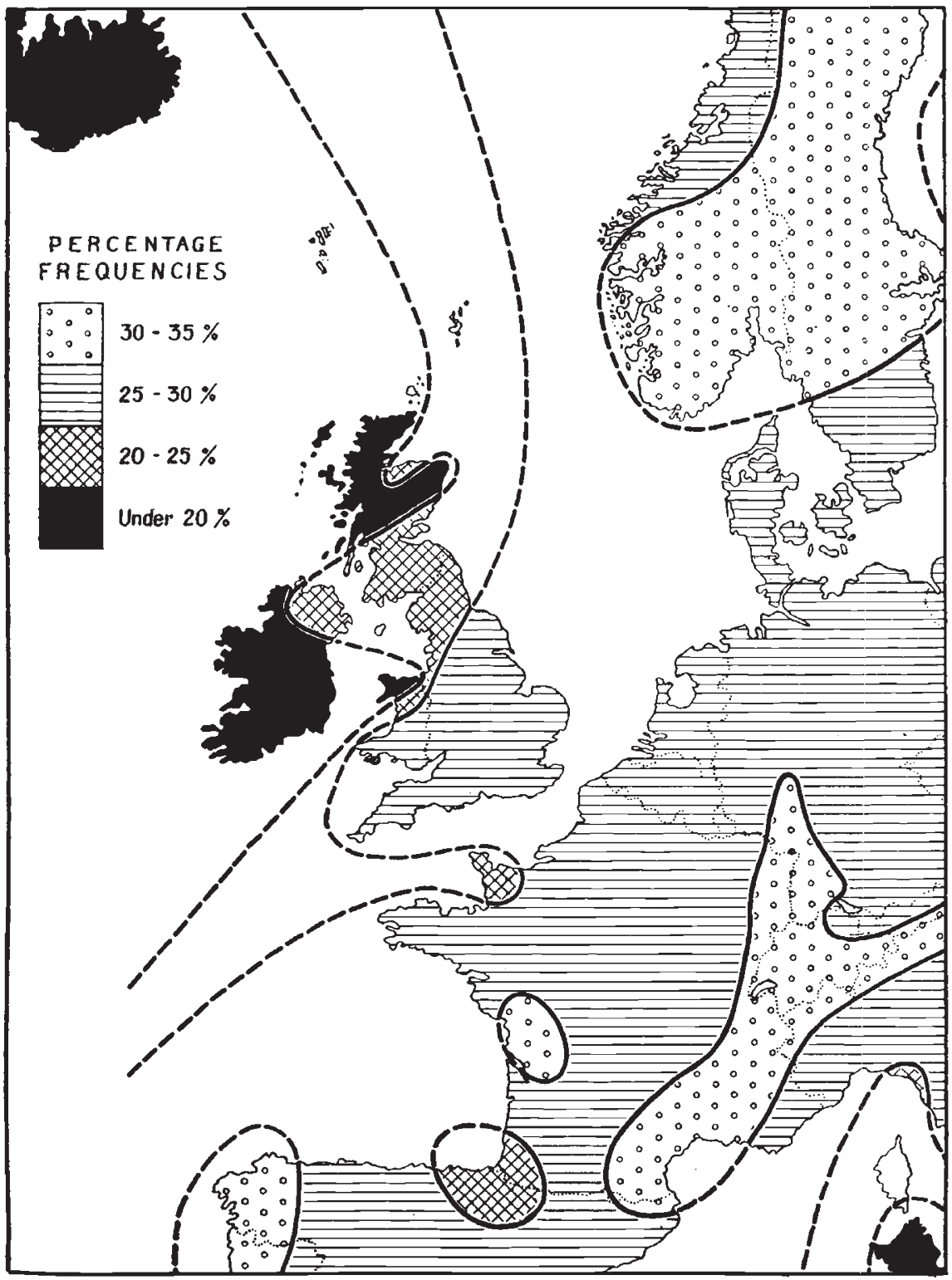

Fig. I.

from the rest of Southern England whilst Brittany, as shown by Vallois, (1949) has $B$ levels but not $O$ levels higher than in the rest of France. 
Special regions.-The Basques of South-western France and Northern Spain have a high $O$ frequency together with the lowest $B$ frequency in Europe by a considerable margin.

The Sardinians, the Cretans, the peoples of the Western Caucasus, and certain Berber tribes of North Africa show $A B O$ frequencies almost identical with those found in the peripheral north-western regions of Europe-Iceland, Scotland, Ireland, and parts of Wales. Whereas, however, the latter populations live between a low $B$ area and the ocean, the Caucasians and Berbers are surrounded by populations with a very high $B$ frequency so that their relatively low $B$ frequencies are remarkable and show a lack of interbreeding with their neighbours. Berber tribes with a high $B$ frequency may have interbred with non-Berber neighbours.

\section{(ii) $\mathrm{Rh}$}

The $R h$ blood groups form a complex system and need some introduction, especially since the available sets of observations vary widely in the degree of their serological and genetical subdivision of the population. Many surveys divide individuals solely into the categories " $R h$-positive" and " $R h$-negative." $R h$-positives are of the genotype $D D$ or $D d$, while $R h$-negatives are $d d$. The presence of the gene $D$ in the genotype determines the presence of the serologically detectable antigen $D$ on the red blood cells. The complete $R h$ blood group system is, however, determined by a set of genes at three closely linked loci on a chromosome, which may be occupied respectively by the genes $C$ or $c, D$ or $d$ and $E$ or $e$, each gene (with the possible exception of $d$ ) determining the presence of a serologically distinguishable antigen. Other rare alleles ( $\operatorname{such}$ as $C^{w}$ ) at each locus have also been described. The linkages are so close that chromosome complexes such as $C D e$ may for most purposes be treated genetically as single genes. Only one crossover, and that in a father, has ever been described but a deletion of the $C$ and $E$ loci (the true order being $D C E$ ) has been detected (Selwyn, Race and Sanger, 1950). The commonest gene combinations in Europe are $C D e$, cde and $c D E$. The combination $c D e$ is common in Africa. Most, but not all, $D$ negative $(d d)$ individuals are of the genotype $c d e / c d e$. For fuller details the reader is referred to the work of Race and Sanger (1950).

In the present state of our knowledge, the $R h$ groups of Europe appear to show a simpler arrangement than the $A B O$ groups. Over the whole of the Continent north of the Pyrenees, Alps and Carpathians, from the Atlantic to Latvia and the Ukraine, as well as in Northern Italy, differences in the frequencies of the numerous $R h$ genotypes between one population and another seldom reach the level of statistical significance. Individuals who are $D$-negative (genotype $d d$ ) show a frequency never far from 16 per cent., indicating a gene frequency of 0.40 for $d$ and 0.60 for $D$. The approximate frequencies of the 
principal $R h$ chromosomes are $C D e$ (including $C^{w} D e$ ) o $4^{\circ}$; cde, o.38; $c D E,{ }^{\circ} \cdot 16$.

The Basques have by far the highest frequency of $D$-negatives of any known population in the world, in the neighbourhood of 30 per cent., together with the lowest $c D E$ frequency in Europe $\left(C D e, 3^{8}\right.$ per cent.; cde, 53 per cent.; $c D E, 7$ per cent.). Similar high frequencies of $D$ negatives have been found among the neighbouring Béarnais and in Galician (N.W. Spanish) emigrants to the Argentine, but the number of Béarnais examined is small and specimens collected in Galicia itself show a very low frequency of $D$-negatives.

Observations on the frequencies of the $R h$ groups in the countries bordering the Mediterranean Sea have, up to now, been rather few and the frequencies found have shown wide variations, making any generalisation difficult. Apart from Northern Italy which resembles North-western Europe, there is a general tendency towards low frequencies of $c d e$ and high frequencies of $C D e$, as instanced by the populations of Ferrara (an isolated part of Northern Italy), several towns in Southern Italy, of Sardinia (Morganti, Panella and Cresseri, I950), and of Galicia (Agosti Romero, Ikin and Mourant, 1950). The $R h$ chromosome frequencies rather closely resemble those found in India. Catalonia (Race et al., I949) shows high values both for $c d e$ and $C D e$ suggesting a mixing of this Mediterranean type with the Basque stock. A distinct subtype is found in Egypt and Iraq (Kayssi, I 949) with a raised $c D e$ frequency suggesting Negro influence.

The observations of Chown, Peterson, Lewis and Hall (1949) on European Jewish immigrants in Canada show that they differ appreciably from all the other peoples of Northern Europe, and suggest a mixing of North European and East Mediterranean components.

\section{(iii) General}

Having examined the distribution of the $A B O$ and of the $R h$ groups we must consider how far these distributions are correlated both with one another and with the findings of anthropologists generally.

It is somewhat surprising to find all over Europe north of the great mountain ranges an almost completely even distribution of $R h$ groups coupled with wide variations of $A B O$, but the two categories do not in fact cut across one another as they appear to do in the Mediterranean area.

In the Basques we find the two systems agreeing fully in demonstrating that this population is one which has mixed very little with its neighbours. While, however, the existing Basques have thus remained unmixed, it is highly probable, as Chalmers, Ikin, and Mourant (1949) have suggested, that a people akin to the Basques once occupied a large part of Europe, and, mixing with mainly $D$-positive invaders, was the main source of the $d$ gene throughout the continent. This suggestion agrees with the long-known physical 
and cultural uniqueness of the Basques and with the fact that Basque place-names extend far beyond the present Basque country.

NORTH WEST EUROPE

DISTRIBUTION OF BLOOD GROUP GENE B

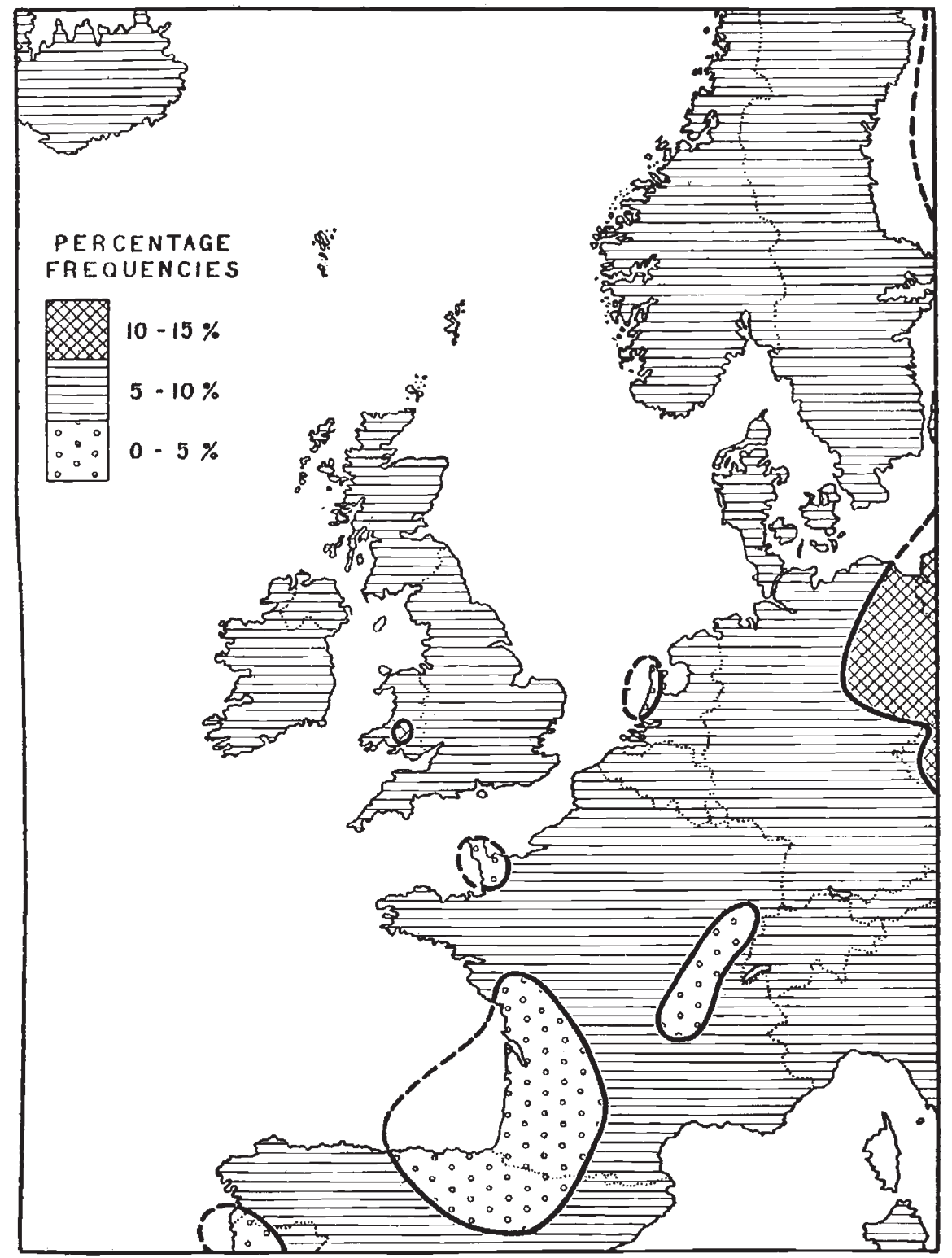

FIG. 2.

When we come to the Mediterranean area, the data are merely suggestive. One is tempted to see a single phenomenon in the 
distribution of populations from Galicia along the Mediterranean and on to Iraq and India, all with high $C D e$ and low cde. It is not

\section{NORTH WEST EUROPE}

DISTRIBUTION OF BLOOD GROUP GENE O

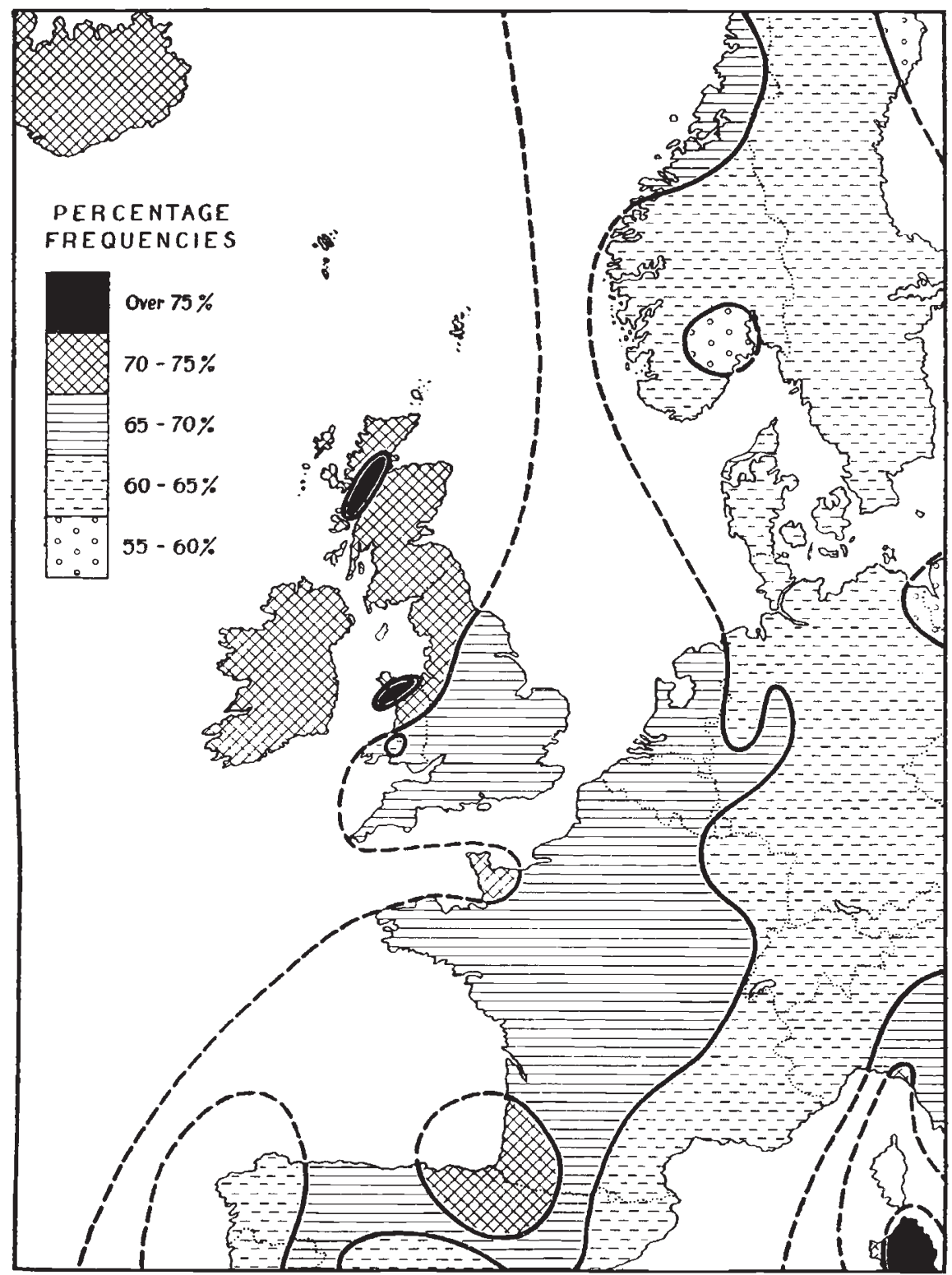

FIG. 3 .

clear why the Sardinians with their $A B O$ distribution closely resembling that of Iceland, Scotland, Ireland, and parts of Wales, should show 
to an extreme degree the very different Mediterranean $R h$ distribution. A series of $R h$ tests on the high group $O$ Berbers and on the Western Caucasians with their similar $A B O$ frequencies is obviously desirable but not readily attainable. A more detailed study of the distribution of the $A B O$ and $R h$ blood groups in the Mediterranean area has recently been made by Mourant (I95I).

\section{ANTHROPOMETRY}

It is beyond the scope of this paper to consider detailed correlations between blood groups and other anthropometric characters, but it is interesting to note them. Fleure and Vallois have drawn attention to resemblances between the late palæolithic inhabitants of Europe and certain small relict populations in islands and mountainous areas. Some of these have been found to show unusual blood group distributions. The Basques are one population showing such ancient skeletal features, and others are found in remote areas of Ireland and Wales, in the Dordogne region of France, in Northern Portugal and in Sardinia. Certain Berbers, and the aboriginal Guanches of the Canary Islands are said to resemble Crô-Magnon man.

Hawkes believes that " a fair proportion of the later inhabitants of Europe have drawn in the network of their descent upon the stocks of upper palæolithic times," whilst Coon, in his survey of living Europeans, puts forward the view that the present-day white race may be reduced to "two least common denominators, the Mediterranean and the Upper Palæolithic group." Fleure and his co-workers, developing the pioneer work of Beddoe, come to the conclusion that there is in Wales " a remarkable persistence of type, a persistence so definite that without the modern Mendelian hypothesis about heredity there would be difficulty in accepting it as a fact." A mountainous country situated at the western periphery of Europe would offer few attractions to later migrants and one is, therefore, not surprised to find in various parts of Wales types of mankind whose distinctions are not transient and accidental, but which date rather from a remote period. The "local types" are, according to Fleure, markedly contrasted with one another and resemble the various racial types identified by anthropologists elsewhere in Europe. The existence of these survivals in considerable numbers in certain districts is explained by him upon a hypothesis of " long persistence or resurgence almost, if not quite, in situ."

Three very remote moorlands in Wales where the skeletal features of the population probably indicate a palæolithic foundation are mentioned by Fleure and James. The physical type encountered differs in an important respect from Crô-Magnon Man and seems to point to some other late palæolithic type. Blood group determinations have been carried out upon a sample of the population of each 
of the three regions, viz. the Black Mountain of Carmarthenshire, the Plynlymon range in Central Wales, and the mountain mass of West Denbighshire termed Mynydd Hiraethog. The results of the analysis are shown in table $\mathrm{I}$.

A GENE FREQUENCY

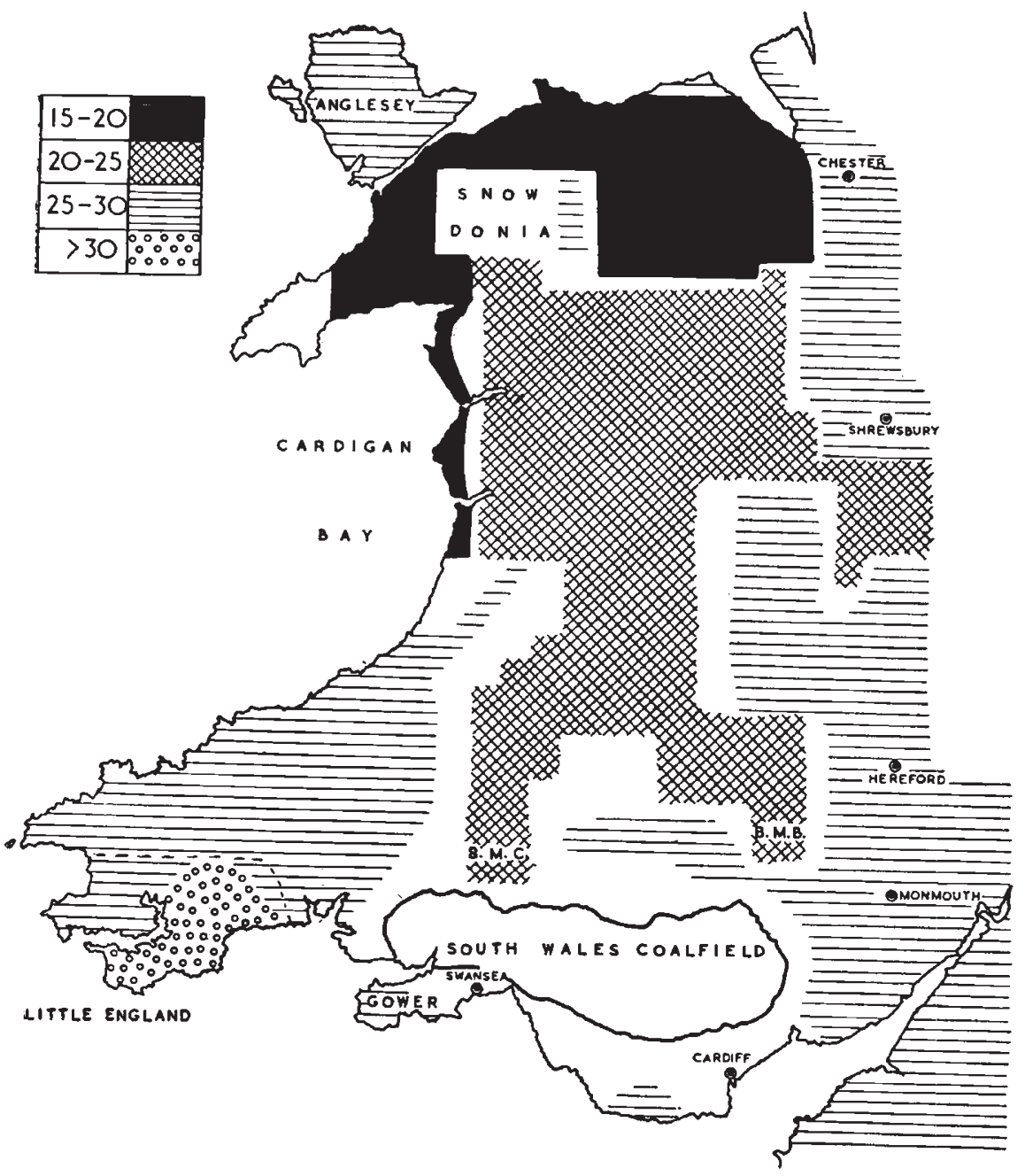

Fig. 4.

It has already been mentioned that the frequency of the $B$ gene is higher in the "Celtic" lands than elsewhere in Western Europe, but in these mountain areas it is higher still (fig. 6). The $B$ gene in Europe as a whole is mainly associated with the Slavonic speaking peoples and this gene in Western Europe may be derived in part 
from the east. The far western rise in $B$ is, however, clearly a different and probably a much older phenomenon.

A consideration of some of the details of the distribution of the $B$ gene in Wales suggests that it may have been introduced at a very early period indeed in the human settlement of the country.

TABLE I

Table depicting the wide variation in the frequencies of the $O$ and $B$ genes in Wales

\begin{tabular}{|c|c|c|c|c|c|c|c|c|c|c|}
\hline \multirow{2}{*}{ Region } & \multirow{2}{*}{ Total } & \multicolumn{4}{|c|}{ Group frequencies } & \multirow{2}{*}{ 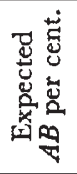 } & \multirow{2}{*}{ 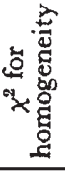 } & \multicolumn{3}{|c|}{ Gene frequencies } \\
\hline & & 0 & $A$ & $B$ & $A B$ & & & 0 & $A$ & $\boldsymbol{B}$ \\
\hline Coastal Ardudwy & $55^{\circ}$ & $55^{\cdot 8}$ & $29 \cdot 8$ & $10 \cdot 7$ & $3 \cdot 6$ & $2 \cdot 4$ & $2 \cdot 43$ & $75 \cdot 2$ & $17 \cdot 9$ & $6 \cdot 9$ \\
\hline $\begin{array}{l}\text { Cardigan Bay } \\
\text { Aberystwyth) }\end{array}$ & 176 & $55 \cdot 7$ & $29 \cdot 6$ & II $\cdot 4$ & $3 \cdot 4$ & $2 \cdot 6$ & 0.37 & $74 \cdot 9$ & 17.8 & $7 \cdot 3$ \\
\hline Mynydd Hiræethog & 121 & $5^{6 \cdot 2}$ & $24 \cdot 8$ & $16 \cdot 5$ & $2 \cdot 5$ & $3 \cdot I$ & $O \cdot H I$ & $74 \cdot 7$ & $15 \cdot 0$ & $10 \cdot 3$ \\
\hline Upper Severn Systern . & 1780 & $53 \cdot I$ & $35 \cdot 17$ & $8 \cdot 3$ & 3.4 & $2 \cdot 3$ & $7 \cdot 02$ & $73 \cdot 3$ & $2 \mathrm{I} \cdot 2$ & 5.5 \\
\hline $\begin{array}{l}\text { Black Mountains (Brecknock and } \\
\text { Adjacent Wye Valley) }\end{array}$ & 713 & $52 \cdot 7$ & $3^{6 \cdot 0} \cdot$ & $8 \cdot \mathrm{I}$ & $3 \cdot I$ & $2 \cdot 3$ & $x \cdot 28$ & $72 \cdot 9$ & $21 \cdot 7$ & 5.4 \\
\hline Southern Massif & 1094 & $44^{\circ} 6$ & $36 \cdot 4$ & $\mathrm{I} 4 \cdot 4$ & $4 \cdot 6$ & $4 \cdot 7$ & $O \cdot O T$ & $66 \cdot 8$ & $23 \cdot 2$ & $10 \cdot 1$ \\
\hline $\begin{array}{l}\text { Black Mountain (Carmarthenshire) } \\
\text { Plynlymon (Southern Side). }\end{array}$ & $\begin{array}{l}16 I \\
238\end{array}$ & $\begin{array}{l}39 \cdot 8 \\
36 \cdot 5\end{array}$ & $\begin{array}{l}29 \cdot 8 \\
39 \cdot 9\end{array}$ & $\begin{array}{l}24 \cdot 2 \\
18 \cdot 9\end{array}$ & $\begin{array}{l}6 \cdot 2 \\
4 \cdot 6\end{array}$ & $\begin{array}{l}6 \cdot 9 \\
7 \cdot 6\end{array}$ & $\begin{array}{l}0.07 \\
1 \cdot 72\end{array}$ & $\begin{array}{l}62 \cdot 8 \\
50 \cdot 6\end{array} \mid$ & $\begin{array}{l}20 \cdot 3 \\
26 \cdot 6\end{array}$ & $\begin{array}{r}16.9 \\
13.8\end{array}$ \\
\hline 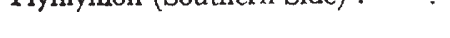 & & 303 & 299 . 30 , & & & & & & & \\
\hline
\end{tabular}

Note $-\chi^{2}$ of the (expected-observed) $\mathrm{AB}$ has, of course, been calculated from the observed numbers. Owing to the extent of the area, the Upper Severn System displays the heterogeneity which is characteristic of Central Wales as a whole.

The main facts can be summarised as follows :-

(i) The $B$ gene reaches its greatest frequency in those regions where the physical anthropologist informs us that the present population contains a palæolithic foundation.

(ii) Even within such areas, however, there is a variation in the frequency of $B$, but the lower value noted on Mynydd Hiraethog agrees with the independent observation of Fleure that "the palæolithic element is less well-marked" in this region.

(iii) The $B$ frequency, though lower than in the above-mentioned areas, is, nevertheless, still high in areas where Fleure postulates the existence of a good foundation of early neolithic stock--a stock into which earlier population components had very probably been assimilated. The southern massif extending from North-eastern Carmarthenshire across Northern Brecknock into North-western Radnorshire is one such area.

In the Welsh Basin of the Severn where, according to Fleure, the early neolithic type is manifestly mixed with a tall, fair element, probably coming in across the English border, the frequency of $B$ falls to a figure as low as that found in Southern England. 
These facts and, in general, the existence of high $B$ frequencies among people dwelling on the inhospitable moorlands of Walesthe areas where one would expect the earlier arrivals to have been driven by the later invaders-lead to the suggestion that a high $B$ wave entered the country not merely before the moderately high $A$ current, but probably even before the very high $O$ stream. Relics of the former much wider distribution of the high $B$ people are probably to be seen in the moderately high $B$ frequencies found elsewhere in Wales as well as in Ireland, Scotland and Brittany.

There is a strong contrast to be observed between the blood groups of the Basques who have the lowest $B$ frequency in Western Europe, and this relict population in Wales which has the highest. There is some evidence that both of these populations have been present since palæolithic times and that both were once more widely spread than at present. The suggestion of Chalmers, Ikin and Mourant (1949), and of others, that the ancestors of the Basques once occupied much of Western Europe is thus only a partial key to a situation which may have been as complex as it is to-day.

The close similarity of blood groups between Iceland on the one hand and Scotland, Ireland and parts of Wales on the other, and the difference between Iceland and Norway is a problem of great interest. Donegani, Dungal, Ikin and Mourant ( $195^{\circ}$ ) have for various reasons suggested that the original colonists of Iceland may have come mainly from the British Isles, only a relatively small number of a ruling class having come from Norway. Taylor and Fisher (I940) incline to the alternative view that the Icelanders are representatives of the Norwegians of the time of the colonisation, since replaced in Norway by later migrants. Further anthropological investigations at present in progress in Iceland and Western Norway will, it is hoped, shed more light on this question. In support of the former view, however, is the recent discovery that in a certain area of Wales where the available evidence had already pointed to the existence of a Viking colony, the $A$ gene frequency of the inhabitants is as high as that of modern Scandinavians. In the comprehensive account of the $A B O$ blood group findings in Wales and the Marches which one of us (I.M.W.) hopes to publish shortly, further details concerning this Viking settlement will be given.

That there should exist in most of North Wales, in some mountain regions of South Wales, in Ireland, in Scotland and, to a certain extent, even south of Hadrian's Wall, people whose'ABO group frequencies are almost identical with those of certain tribes belonging to the North African White Race may, at first sight, seem rather strange. Nevertheless, there is much evidence-anthropological, archæological and linguistic-to suggest that such a finding is more than an accidental coincidence.

The correspondence in the physical anthropology of the two sets 
of people was noted by the authors of Libyan Notes (I9oI). Ther state that the Chawia, for example, are remarkably European in their appearance. Many might pass for Irishmen or Scotsmen. The

\section{B GENE FREQUENCY}

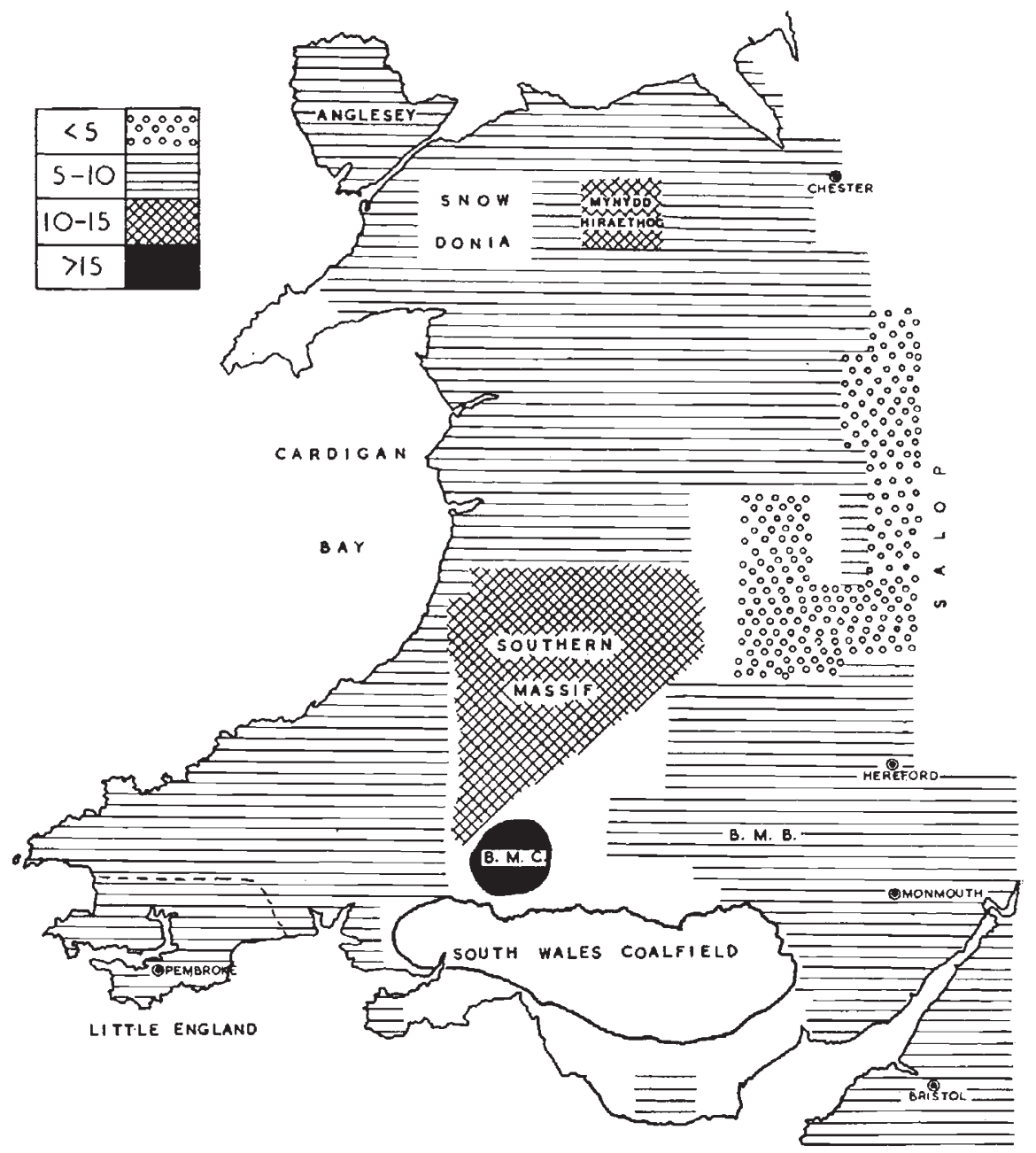

FiG. 5.

children, especially the boys, could if suitably attired, be placed in a class of British pupils and remain almost indistinguishable.

There is abundant archæological evidence linking the Mediterranean basin with Western Britain and Ireland. Cultural relations appear to have been strongest during the neolithic period-the epoch which witnessed the erection of our megalithic monuments. According to Grimes, " the study of the two provinces of North and South Wales 
suggests that it was the northern area "-the high $O$ area on our map-" which received the western megalithic culture in its greatest vigour."

\section{O GENE FREQUENCY}

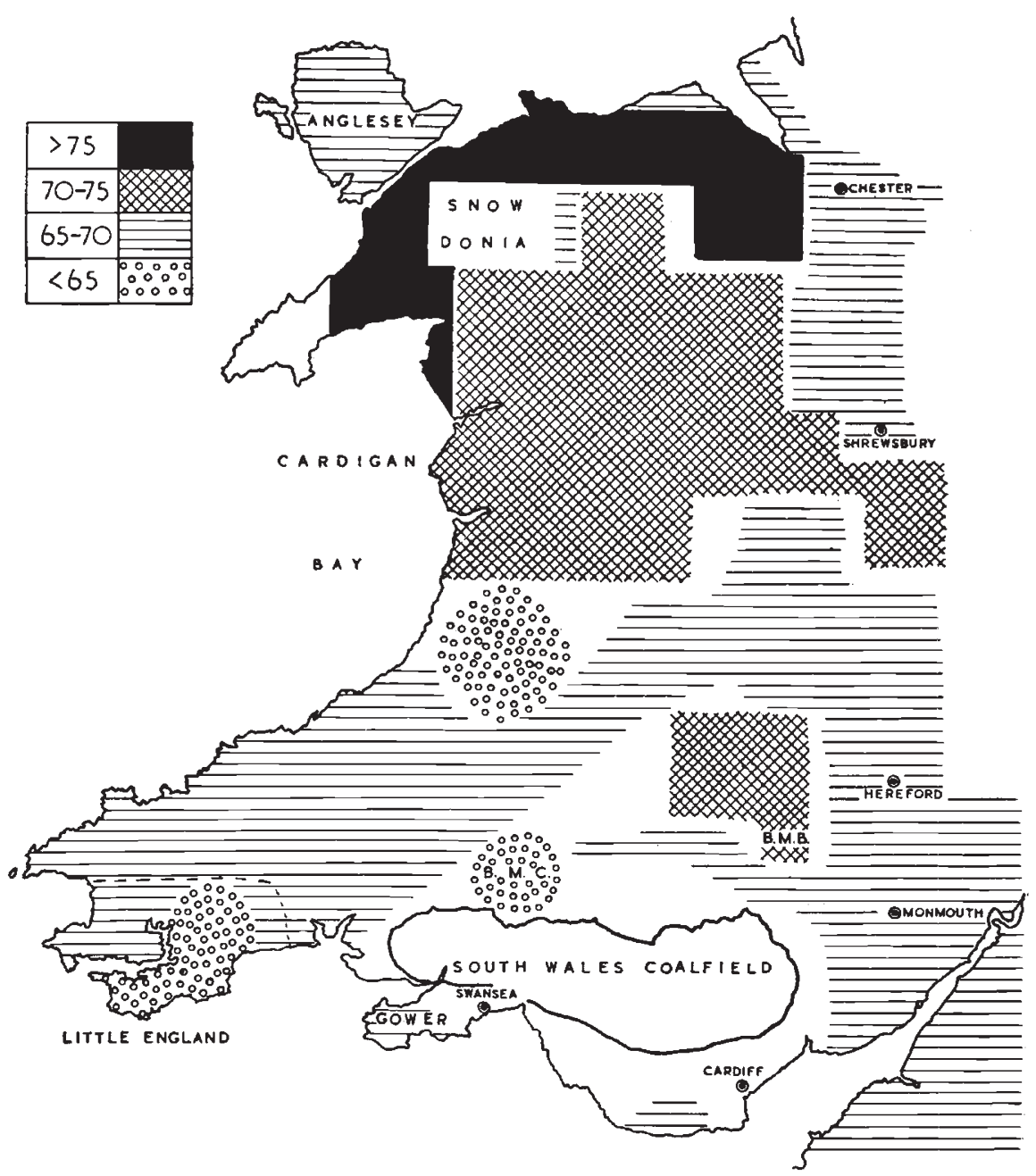

FIG. 6.

\section{LANGUAGE}

(i) Philology

Philologists usually distinguish three different elements in language - sounds, grammar and vocabulary. Many of the older writers held the view that linguistic unity implied racial unity. After the fallacy of this opinion had been exposed, it came to be thought that race 
and language were wholly independent of one another. Recently, however, it has become apparent that race plays an important rôle in the determination of the phonetics of a given language. Semantics, on the other hand, are essentially cultural whilst grammar is probably the product of several influences. Even if we disagree as to the width of the gulf between race and language it nevertheless seems reasonable to assume that the further one recedes in point of time the narrower does this gulf become. This is especially so in the case of isolated populations. The Basques are the only people in Western Europe who speak a language that does not belong to the Indo-European group. Thus we see that blood groups, both $A B O$ and $R h$, skeletal characters and language all converge to show that the Basques are distinct from the other peoples of Western Europe. The Basque question is treated, more fully than it can be here, by Chalmers, Ikin and Mourant (1949).

The linguistic peculiarities of the tongues spoken in some of the westernmost outposts of Europe have attracted the attention of many philologists, but nowhere have their researches been more intense than upon the structure of those languages which are termed Celtic.

It is well known that the ancient Celtic tongues have at some time been spoken in all parts of the British Isles. The exact period of their introduction is a matter of dispute, but Pokorny believes that it was coeval with the arrival of the Urnfield Folk, which, according to Fox, was about the eighth century B.c. Though English has replaced them over the greater part of our islands they have, nevertheless, survived in Ireland, Wales, the Isle of Man, and the Scottish Highlands. The Welsh language, together with Armorican and extinct Cornish, form the Brythonic group, whilst Erse, Manx, and Scots Gaelic make up the Goidelic branch. Celtic in its turn belongs to the Indo-European family.

Prior to the arrival of Celtic speech in our islands the inhabitants must have carried on their daily affairs by means of some spoken language, and it, therefore, is of interest to try to ascertain something of the nature of the language which immediately preceded Celtic.

Those who, at the present day, live towards the eastern periphery of Wales where Welsh is gradually giving way to English are witnesses of a process identical with that which must have taken place in Britain over two thousand years ago - the replacement of one language by another. The result is illuminating, for one sees that even in times when a certain degree of education is universal, the replacement is usually far from complete even to the casual hearer, and often decidedly less so to the grammarian. What is largely " a mixed language" ensues in the common parlance though not in the cultured tongue.

In the older language, vocabulary appears to suffer most. When Welsh gives way to English as the individual's mother tongue, relativcly few words are handed on from the older to the newer language. 
A good illustration is to be found in Old English, which contains but few words derived from its predecessor in England, Brythonic. The present speech of Gascony offers a further example, for though Basque was at one time the language of that region, yet the French dialect of that region to-day contains hardly a word derived from Basque. A search of the Celtic languages for the presence of non-Indo-European words is not, therefore, likely to meet with any great success except in the names of places, of rivers, of mountains, and of valleys, which have a much greater tendency towards permanence. In fact most of the river names in England to-day are Celtic, whilst some may date from an even remoter period. It has recently been shown that in France most of the river names, a great many names of hills, rocks and caverns, and those of many plants and trees are derived from a pre-Celtic language. Furthermore, a comparative study of such names in other European countries has revealed the existence of a common linguistic origin to these terms. The famous Welsh mountain which is similar in shape to a mighty chair and bears the name Cader Idris (Idris' Chair) seems to suggest that Idris was an important personage. When one considers that a line of Berber kings also bore the name of Idriss the coincidence seems noteworthy. It would appear then that long before the invasions of Celtic-speaking tribes much of Europe and also perhaps North Africa was inhabited by a people speaking a common non-Indo-European tongue.

Syntax and idiom, intonation and accent are, however, more stable than vocabulary. In 1621 , Dr John Davies, the reviser of the I 588 translation of the Welsh Bible drew attention to the peculiarities of syntax in the Welsh version. He showed that they were alien to Greek and Latin as well as to Hebrew. Much later Rhys mentioned that certain aspects of Welsh syntax as well as some Welsh words were undoubtedly non-Indo-European. Zimmer came to a similar conclusion. Morris Jones was the first to investigate the pre-Aryan syntax in Celtic in a detailed manner. His conclusions have largely been confirmed by Pokorny who has made an exhaustive study of the question with special reference to Irish and has come to the conclusion that " the Gelts show in the whole structure of their language a close affinity to the language of the White Mediterranean peoples of North Africa."

A brief summary of some of the more interesting points on syntax put forward by the two last-named workers is given in the Appendix.

Ogham inscriptions are known from Cornwall, Wales, Ireland, Scotland and even as far north as the Shetlands, and among those that are fairly legible there are some of which it can be stated that a knowledge of the Celtic languages has been of little avail in the attempt to translate them. They appear to be written in a language termed by Rhys "Pictish"-a non-Indo-European tongue spoken in the British Isles before the advent of Celtic-speaking people. Latin inscriptions construed in peculiar grammar have also been discovered. 
The syntax of these is non-Indo-European and of a type commonly found in agglutinative languages like Basque. Of this peculiar syntax Rhys states: "it occurs in our inscriptions too frequently to be regarded as a slip."

Intonation persists to such a degree that even an educated Welshman can with fair ease be detected by the intonation of his English speech, and the rank and file by idiom and syntax in addition. In parts of Radnorshire where Welsh disappeared as long ago as two centuries, these hallmarks still remain. Even in Hereford town where Welsh has not been spoken since the sixteenth century, the speech intonation that can be heard on a market day is, according to Ganon Bannister, still manifestly Welsh. An observer who stood listening to a conversation at such a distance that the words could not quite be caught, he noted, would be convinced that the conversation was proceeding in Welsh and not in English. Traces of a similar intonation may be observed in parts of Gloucestershire and even as far east as Oxfordshire.

The lilting type of intonation found in Ireland and in much of Wales and the Marches, which is so alien to standard English, may also be observed, according to Byrne, in some of the North African languages. This finding has not, so far, been confirmed.

It is but a short step from language and its intonation to oratory, and one of the distinguishing features of pulpit oratory in Wales is the hwyl. To drive his message home more effectively, the preacher may depart from normal speech in sermon delivery and proceed in the form of a chant. The greater the response from the congregation -in Nonconformist Wales this can, in large measure, be judged by the frequency of the exclamations of approbation-the more fully developed is this chant liable to become. All preachers do not follow the identical musical score, but the underlying pattern is the same in all cases.

T. Gwynn Jones was the first to draw attention to the similarity of the Welsh hwol to the chant of the African Muezzin. More recently, the B.B.C. produced a feature programme upon the subject. Sound recordings of some Welsh preachers on the one hand, and the white North African's call to prayer on the other, were broadcast. The two were strikingly similar. But the record of one Welsh preacher in a fervent hwoyl was apparently so very nearly identical with the Muezzin's chant that it was possible to interplay the records and, unless one made a special effort to grasp the words, it was impossible to discover where the North African was cut out and his place taken by the Welsh preacher.

\section{(ii) Phonetics}

Linguistic problems may, however, be approached from quite a different angle from the above. Darlington has given reasons for supposing that the sounds of a language as distinct from its ctymology 
and grammar are largely in the long run determined by genetical characters of the vocal organs. In particular, he has shown that there is a close correlation in Europe between a high frequency of the blood group $O$ gene and the presence of a th sound in the language. It would be interesting to see this supported by anatomical data.

We have seen that the Basques are probably a particularly pure relict race. They have a high $O$ frequency and a strongly developed th sound (or rather a th sound usually represented in writing by the letter z). If, therefore, only one stock has happened to carry the combination of many $O$ genes and the ability to pronounce th, we should expect to find a large proto-Basque element in all the high group $O$ th speakers, and hence a high correlation between the typically Basque $d$ gene, the $O$ gene and the th-speaking character. Alternatively, the Basques may represent a fusion of an $O$, th-speaking stock with a $d$ stock.

We have noted that in several regions in the Old World showing a similarity in blood group frequencies of their inhabitants, the languages spoken also display a number of phonetic peculiarities in common. A detailed examination of this most interesting problem is, however, beyond the scope of the present paper but we may mention two examples, the $l l$ in Welsh and Icelandic, and the mutation of consonants in Welsh and Irish and also in the Sassaric dialect of Sardinia.

\section{ANCIENT RECORDS}

Historians and early chroniclers have added to our knowledge of ancient Britain. That there were distributed in the far west of Europe -in an area apparently similar to that in which people of very high $O$ frequencies are found to-day-national communities completely distinct from the Celts, was known to Herodotus. "The Celts," he writes, " are outside the Pillars of Hercules and they border on the Kynesii who dwell the furthest away towards the west of the inhabitants of Europe." He repeats the statement in his fourth book where he states that the Celts are the furthest away towards the setting of the sun, "with the exception of the Kynetes" (sic).

The duality of the population in Southern Britain at the time of the Romans is considered by Huxley to be " one of the few fixed points in British ethnology." Strabo informs us that the prisoners taken in the south-eastern part of Britain were six inches taller than the tallest men in Rome. Their colouring was blond. In the interior on the other hand, there dwelt according to Caesar, a vastly different people who regarded themselves as the autocthonous children of the soil. The swarthy visages and twisted locks of the South Welsh tribe of Silures, states Tacitus, pointed to their Iberian origin. (The territory occupied by the Silures includes the high $O$ area of the Brecknock Black Mountains and the adjacent Wye Valley.) The very name "Silures" has defied an explanation from Celtic sources. 
The customs of these aboriginal islanders contrasted materially with those of the later comers who differed in this respect but little from the Gauls. The institution of marriage, as practised by the Romans, was unknown to the former and, as a consequence, every relationship was counted through the mother. Schrader states that the primeval Aryan family was, on the other hand, patrilineal. In referring to the matrilineality of the early inhabitants of Britain Zimmer writes : "Auf einen Piktenherrscher und seine Brüder folgt nicht etwa der Sohn des ältesten, sondern der Sohn der Schwester." Amidst the Berbers and in other parts of the East, the same state of affairs exists to this day. Hanoteau states of the former: "Quand le roi meurt ou est déposé, ce qui arrive assez souvent, ce n'est pas son fils qui est appelé à lui succéder, mais bien le fils de sa soeur."

At what period the non-Indo-European tongue of the British Isles became extinct is not certain, but it appears not to have been long dead in Munster when Cormac wrote his Glossary in the ninth century A.D. He refers to it as the "iron language "-a name which it received on account of the difficulty of seeing through it, and owing to the darkness and compactness of its texture.

Adamnan wrote the Life of Columba towards the close of the seventh century and his work is available to us in a manuscript from the eighth. He relates how Columba, after having come over from the north of Ireland to Britain, went on a mission to Brude, King of the Picts, whose stronghold lay near the mouth of the river Ness. To the king and his court he had no difficulty in making himself understood, but on journeying inland one reads of his preaching to the peasants with the aid of an interpreter. At a later date, on the island of Skye, two young men brought their father to him to be baptised. Here again, he was forced to enlist the services of an interpreter although the convert bore the Celtic name of Artbrannan.

That these were far more than dialect differences which could easily be mastered is pointed out by Rhys. Furthermore, intra-Gaelic dialect differences were, at most, of relatively little importance at this early stage. The conclusion one can draw is that the language was pre-Celtic.

Bede lists the people of Britain in whose languages Christianity had in his day to be taught as being the Angles, the Brythons, the Scotti, the Picts and the Latins. The language of the Picts was, therefore, distinct from that of the Scots-Gaelic, and from that of the Brythons. Rhys states that the significance of Bede's words is sometimes explained away by supposing Pictish to have been a Celtic dialect lying somewhere between Brythonic and Goidelic. There is, however, little reason to suppose that this was Bede's view; for in the case of English he was content to let the language of the Angles stand for all dialects without mentioning, for instance, that of the Saxons. 


\section{DOMESTIC ANIMALS}

Much information on human migrations may be gleaned from a historical study of the genetics of those domestic animals to which early man was perforce bound. Adametz was the first to study this question in a scientific manner. According to him, the primitive North African long-horn cattle and the greyhound are native to the Hamitic north of the African continent. The long-horns have not only spread throughout North-eastern and South Africa, but across Spain (Andalusian cattle) and as far as Britain where the Black Cattle of Wales and the Reds of Devon are the undoubted descendants of the early North African stock, whilst the Herefords and the Highland cattle are very probably so. The Scottish deerhounds and the Irish wolfhounds are, according to Hilzheimer, crosses between the Hamitic greyhound and Scottish and Irish wolves respectively. It may become possible in the near future to test some of these relationships by means of the blood groups of the animals concerned.

\section{CONCLUSION}

In view of the evidence presented there appear to us reasonable grounds for the belief that, prior to the advent of Celtic-speaking immigrants, the British Isles were inhabited by a people whose domain had at one time extended over a considerable part of Europe and North Africa but who under ever increasing pressure from the east had been driven from their homelands. Some, no doubt, found refuge in the more isolated mountain regions, but the remainder were gradually driven westwards and finally came to occupy a limited area near the Atlantic seaboard of Europe. That the descendants of these people have, to this day, remained largely unmolested in those parts of our islands furthest away from the ancient land connection with the continent of Europe seems demonstrated in the distribution of their $A B O$ genes, which singles them out from the other people of Northern Europe, excepting the Icelanders, but links them with the Berbers and other communities living on the Mediterranean shore and in the Middle East.

The pattern upon which the early peregrinations of Homo sapiens was woven is gradually becoming clearer, but the main lesson to be drawn is the need of correlation of the steadily accumulating blood group data with all the other sources of information-physical, cultural, linguistic and documentary.

\section{SUMMARY}

I. In Europe three main zones of $A B O$ blood group distribution can be distinguished, one of relatively high $B$ in the east, one of high $A$ in the centre and west and one of high $O$ in the extreme west, with $B$ slightly but significantly more frequent than in the central zone. 
The $R h$ groups are fairly evenly distributed in Northern and Central Europe with about i 6 per cent. of $R h$-negatives. The frequency of $R h$-negatives is about 30 per cent. in the Basques and varies from 5-16 per cent. in Southern Europe.

2. Wales displays significant local variations in the frequencies of the $O, A$ and $B$ genes. On the remoter moorlands where physical anthropologists postulate the existence of very early human stocks, $B$ gene frequencies exceeding to per cent. are common, and in the Black Mountain of Carmarthenshire even exceed 16 per cent. In the Marches they fall below 5 per cent.

3. Apart from one or two mountain regions in South Wales, very high $O$ gene frequencies of 70-75 per cent. similar to those found in Scotland and Ireland are confined to the north of the principalitya fact which supports the obvious view that a less accessible North Wales has not been subjected to the human migrations which have affected the southern half of the country.

4. It appears that a high $B$ wave entered Wales not merely before the moderately high $A$ current, but probably even before the very high $O$ stream. It has formerly been supposed that populations with high $B$ frequencies were among the latest to enter Europe and were confined to the east.

5. $O$ frequencies similar to those in North Wales, Scotland and Ireland are also to be found among the Berbers in North Africa and elsewhere in the Mediterranean region. That the early inhabitants of Western Britain had strong White North African affinities is suggested by the pre-Aryan syntax of Celtic. Philologists have pointed out that " the Gelts show in the whole structure of their language a close affinity to the language of the White Mediterranean peoples of North Africa."

\section{APPENDIX}

\section{Pre-Aryan survivals in Celtic syntax}

It is contended by Morris Jones and Pokorny that if the pre-Celtic inhabitants of Britain are related to the Berbers of North Africa it is not unnatural to expect that their language should also have belonged to the Hamitic family-a family which includes the Berber languages and ancient Egyptian.

It is known that Egyptian preserves a form of Hamitic speech and there is reason to believe that it approaches the ancient type of Hamitic language much more closely than any of the modern Berber dialects. Consequently, it is Egyptian that one expects to bear the greater resemblance to the pre-Celtic speech of our islands.

\section{(i) Sentence connections}

One of the most characteristic features of the neo-Celtic languages is the tendency to break speech into a scries of direct clause statements. Instead of there being a single sentence of some length comprising one or more subordinate clauses, as is seen in Latin, English, German, etc., one finds a sequence of short simple sentences. As it is rccognised that subordination of sentences is commoner in written than in spoken language, the relative rarity of subordination in written Irish is all the more remarkable and suggests that the agglutinative character of the language 
is fundamental. The Indo-European relative sentence is not mirrored in the neo-Celtic languages except partially. A basic difference exists between a relative sentence in which the relative is the subject or object and that in which it is in an oblique case. Personal pronouns such as " whose," " of whom," " of which," corresponding to the Latin "cuius," "quorum," "quarum," are absent. For example "I gave it to the man who delivered the bread" can be rendered into Irish or Welsh on the same relative Indo-European pattern as in English. But "I gave it to the man whose house lies at the top of the hill" cannot. It would seem as though a statement such as the latter was divided up in ancient times somewhat as follows: "I gave it to the man. The man's house lies at the top of the hill." A gradual infiltration of Indo-European influence in this particular can be noted as one advances through the centuries from Old Irish and Old Welsh to the medixval forms and on to modern speech.

It is well known that the asyndeton-a figure of speech which omits connectives, as "I came, I saw, I conquered "-plays an important rôle in Egyptian. There is an aversion from the use of subordinate sentences in both Egyptian and Berber. Thus, Irish and Welsh in the essentials of their speech construction point unmistakably towards North Africa.

\section{(ii) Word order}

The relation of words in the Indo-European sentence being sufficiently demonstrated by inflexions, the order of words may vary, but it is the verb which usually comes last. In Irish and Welsh, on the other hand, the verb normally comes first: thus, in Welsh, Cododd Arthur y garreg, "Arthur picked up the stone" ; in mediæval Irish, Aliss Patricc Dubthach, " Patrick requested Dubthach." O'Donovan tells us in his Irish Grammar that "In the natural order of an Irish sentence the verb comes first, the nominative with its dependents next after it, and next the object of the verb." Ranouf in his Egyptian Grammar writes : "The order of the words in an ancient Egyptian sentence is constant. When the verb is expressed, it precedes the subject. If both the nearer and the remote objects of a verb are nouns, the former is placed after the subject and the latter comes last."

There is a special form of sentence in Welsh in which a noun as subject comes first. This order is used to lay particular stress upon the subject; thus Duw a farn . . .; for $\left(r_{s}\right)$ Duw a farn ... ; " (it is) God who judges ..." Similar syntax may be heard in the English spoken on the streets of Cardiff on the occasion of an international rugby match ; thus, "From the Rhondda I am" for "(It is) from the Rhondda I am." In Egyptian, according to Ranouf, " a noun at the beginning of a sentence implies the ellipsis of the verb "to be '."

In both Irish and Welsh an adjective, or noun in the genitive case, is placed after the noun which it qualifies ; in Welsh gwr mawr, Irish, fear mór " a great man." The same order exists in Egyptian. Bergaigne has pointed out that the qualifying word, whether adjective or genitive, came before the word in the primitive IndoEuropean sentence. There is, therefore, in Irish and Welsh a divergence from the primitive Aryan order in the sentence and its replacement by the same order as is found in Hamitic-a divergence which is also noticeable in some of the Romance languages which, as is known, display in the syntactical field certain pre-Aryan traits.

\section{(iii) Inflected prepositions}

In the neo-Celtic languages when the object of a preposition happens to be a personal pronoun, it becomes attached to the preposition in a manner identical with an inflexion. The fusion is complete for the appendage is not even hyphenated ; thus in Welsh " us" is $n i$, but "for us" is not er ni, but erom. In Egyptian the endings forming personal verbs are also affixed to prepositions.

The preposition $y n$ which cannot be adequately rendered into English by a single word is so remarkably like the Egyptian em in its syntactical usages that 
mention must be made thereof. In common with other prepositions, both the Welsh $y n$ and the Egyptian $e m$ take pronominal suffixes, as explained above; both are used in the sense of "in" before a place name; both are used to introduce the complement after verbs of being and becoming. Their chief characteristic is their usage as introduction in every kind of complement. In like the Egyptian em is used after the verb " to be" to introduce not only an attributive substantive but also an attributive adjective.

\section{(iv) Periphrastic conjugations}

In Egyptian one of the commonest forms of periphrastic conjugation is as follows :- $(a)$ verb " to be" followed by a noun or having a personal suffix joined to it; $(b)$ a preposition; (c) verbal noun. Although Irish and Welsh retain many Indo-European tenses, the type of conjugation mentioned above is, nevertheless, extremely common. In Egyptian, the preposition em, "in," er " to " or "for," her "above" or "upon" are used to indicate the present, future and perfect tenses respectively. In Welsh the corresponding prepositions are $y n$ " in," wedi "after," while am "for," presumably an old future, is now only used optatively. For example : Maent wedi cael breyd (literally) "They are after having food." This docs not mean " they are in quest of food," but the exact opposite "they have had food." Syntax of this kind may also be heard in Irish-English. Yet one must remember that a somewhat similar type of construction is to be found in English, though its source appears unknown, e.g. he is a-coming; a-hunting we will go. Probably it has filtered through to English.

The syntactical features mentioned above with particular reference to Egyptian are exhibited fairly consistently by all the present-day Berber dialects. The Semitic languages which are related to Hamitic also display many of these features, but they agree less closely in syntax with the Celtic languages.

Acknowledgments.-We are greatly indebted to Dr C. D. Darlington of the John Innes Institution and Dr J. R. Fraser Roberts of the London School of Hygicne and Tropical Medicine for offering us a wealth of helpful criticism and advice on several aspects of the work. We thank Dr R. J. Drummond, Medical Director of the National Blood Transfusion Service, Wales, who placed at our disposal the record cards of the area under his jurisdiction and consistently assisted the investigation by arranging blood donation clinics in the areas of greatest anthropological interest. We also thank Dr D. E. Lehane of Liverpool for allowing us to analyse the records of the groupings relating to Anglesea and Cheshire as well as those of Caernarvonshire, Denbighshire and Flintshire which had become available since Dr Fraser Roberts' survey of 1942. We are grateful to Dr W. Weiner of Birmingham who gave us permission to inspect the records of Herefordshire, Shropshire and Worcestershire and to Major R. Deedes, Honorary Organiser of the Transfusion Service in Shropshire, who inaterially assisted us with the sorting of the cards in his area. We also wish to thank Dr H. J. R. Kirkpatrick, Medical Director of the North of Scotland Blood Transfusion Service, Inverness, who has allowed us to use the results of his unpublished analysis of the distribution of the blood groups in northern Scotland.

\section{REFERENCES}

\section{(a) Blood groups}

Agosti romero, L., ikin, ei.IZABetil W., AND mourant, A. E. I950. Les groupes sanguins ABO, MNS et Rh des Galiciens. Rev. Hemat., 5, 325-328.

BOYD, W. C. 1939. Blood groups. Tabul. Biol., I7, pt. 2.

Chalmers, J. N. M., ikin, Elizabeth W., And mourant, A. E. I949. The ABO, $\mathrm{MN}$ and Rh blood groups of the Basque people. Amer. F. Phys. Anthrop., n.s., 7, 529-544. 
ChoWn, B., PETerson, R. F., LeWis, marion, AND hall, ANn. 1949. On the ABO gene and $\mathrm{Rh}$ chromosome distribution in the white population of Manitoba, Canada. 7. Res., E., 27, $214-225$.

DE hOYOs SAINZ, L. 1947. Distribucion de los grupos sanguineos en España. Instituto "Juan Sebastian Elcano," Consejo Superior de Investigaciones Cientificas, Madrid.

Dobson, A. M., AND IKIN, E. w. I946. The ABO groups in the United Kingdom, etc. 7. Path. and Bact., 58, $221-227$.

DONEGANI, JOYCE, DUNGAL, N., IKIN, ELIZABETH W., AND MOURANT, A. E. I950. The blood groups of the Icelanders. Ann. Eugen., ${ }_{15}$, I47-I52.

ETcheVerRy, M. A. I945. El factor Rhesus, su genética e importancia clinica. Dia. Méd., I7, I237-1251.

HART, E. W. I944. An analysis of the blood group composition of a population in Northern Ireland. Ann. Eugen., 12, 89-1 or.

KaYssi, A. 1949. The Rh blood groups of the population of Baghdad. Amer. 7. Phys. Anthrop., n.s., 7, 549-551.

MORGANTI, G., PANELla, I., AND CRESSERI, A. I950. Distribution des types Rh dans la population italienne. Rev. Hémat., 5, 329-333.

moulinier, J. 1949. The $\mathrm{Rh}$ factor in south-western France. Amer. 7. Phys. Anthrop., n.s., 7, 545-548.

MOURANT, A. E. I95I. The blood groups of the peoples of the Mediterranean area. Cold Spring Harbor Symposia on Quantitative Biology, 15 (in the press).

RAGE, R. R., LAWLER, SYLVIA, D., BERTINSHAW, DOREEN ; GRIFOLS LUCAS, J. A., GRIFOLS LUCAS, V., IBARZ ROQUETA, M., AND OPPENHEIMER, W. I949. Los genotipos Rh de 223 dadores de sangre españoles. Medicina Clinica, Barcelona, ${ }_{3}, 325-326$. RACE, R. R., AND SANGER, RUTH. 1950. Blood Groups in Man. Oxford : Blackwell Scientific Publications.

RAGE, R. R., SANGER, RUTH, AND SELWYN, J. G. I950. A probable deletion in a human Rh chromosome. Nature, ${ }^{166,} 520$.

ROBERTS, J. A. FRASER. 1942. Blood group frequencies in North Wales. Ann. Eugen. Lond., II, 3, 260-27I.

ROBERTS, J. A. FRASER. I 948 . The frequencies of the ABO blood-groups in SouthWestern England. Ann. Eugen. Lond., 14, 2, Iog-I 16.

SACHS, H. r940. Some aspects of the problem of blood grouping and the distribution of blood groups in the Irish population. Iris 7. Med. Science, April r 940.

TAYLOR, G. L., AND FISHER, R. A. I940. Scandinavian influence in Scottish ethnology. Nature, 145, 590.

VAllors, H. v. 1944. La répartition anthropologique des groupes sanguins en France et plus spécialement dans le Sud-Ouest. Bull. Mém. Anthrop., Paris, ser. $9,5,53-80$.

vallors, H. v. 1949. La répartition des groupes sanguins en France : l'ouest Armorico-Vendéen. Archiv der Fulius Klaus-Stiftung für Vererbungsforschung, Sozialanthropologie und Rassenhygiene, 24.

\section{(b) Anthropometry}

coon, c. s. 1948. The Races of Europe. New York.

FLEURE, H. J., AND WHITEHOUSE, w. E. Igr6. Early distribution and valleyward movement of population in South Britain. Arch. Camb., ${ }_{1} 6$, Ior-140.

FLEURE, H. J., AND JAMES, T. C. I 916 . Geographical distribution of anthropological types in Wales. 7.R.A.I., $46,35^{-1} 7^{2}$.

FLEURE, H. J. I I20. Some early neanthropic types in Europe and their modern representatives. J.R.A.I., 50, $12-40$.

vallois, H. v. 1943. Anthropologie de la population française. Paris. 


\section{(c) Language}

BEDE. 1912. Historical Works, ed. C. Plummer. London.

BYRne, J. 1885. General Principles of the Structure of Language. London.

Darlington, c. D. 1947. The genetic component of language. Heredity, 1, 3, 269-286.

Dauzat, A. 1940. L'Europe linguistique. Paris.

Dauzat, A. 1946. La Toponymie française. Paris.

Dauzat, A. 1947. Les noms de lieux. Paris.

DAVIES, J. 1621. Antiquae linguae Britannicae. Londini.

hanoteau, A. I86o. Grammaire tamachek'. Paris.

JONES, J. MORRIs. 190o. The pre-aryan syntax in insular Celtic. Appendix B of The Welsh People by J. Rhys and D. Brynmor Jones, London.

lewis, H., AND PEDersen, H. 1937. A Concise Comparative Celtic Grammar. Göttingen.

Meillet, A. 1918. Les langues dans l'Europe nouvelle. Paris.

POKORNY, J. 1927-30. Das nicht-indogermanische Substrat im Irischen. Zeitsch.

f. Celt. Philologie, 16 , 95-144, 23 I-266, 363-394; $17,373-388 ; 18,233-248$.

POKORNY, J. 1933. Origin of the Celts. Nature, 132, 648.

RHYS, J. I879. Lectures on Welsh Philology. London.

TAYLOR, I. 1865 . Words and Places. London.

zimMER, H. 1913. Aus dem Nachlass Heinrich Zimmer's, ed. Kuno Meyer. Zeitsch. f. Celt. Philologie, 9, 87-120.

\section{(d) General}

ADAMETZ, L. 1920. Herkunft und Wanderungen der Hamiten. Vienna.

ADAmnan. 1920. Life of St Columba. (Reeves ed.) Oxford.

BanNister, A. T. Personal communication.

B.B.C. Welsh Home Service feature programme $r_{r}$ hwyl gymreig. Produced by

A. Talfan Davies, 2nd December 1945 .

caesar. De Bello Gallico, 5, 14.

CORMAC. 1912. An Old Irish Glossary, ed. Kuno Meyer. Halle.

DANIEL, G. 1950. A Hundred Years of Archeology.

Fox, c. 1947. The Personality of Britain. Cardiff.

GRIMES, w. F. 1936. The megalithic monuments of Wales. National Museum of Wales, reprint from Proceedings of the Prehistoric Society, 1936.

hawkes, c. 1940. The Prehistoric Foundations of Europe. London.

HERODOTUS. 2,4 .

hilzheImer, M. 1926. Natürliche Rassengeschichte der Hcustiere. Berlin.

HUXley, T. H. I89o. Critiques and Addresses. London.

JONES, T. GWYN. 1912. Môr canoldir a'r Aifft. Caernarvon.

RANDALl-MaCiVER, D., AND WILKIN, A. I901. Libyan Notes. London.

RHYS, J. I904. Celtic Britain. London.

SCHRADER, O. 1890. Sprachvergleichung und Urgeschichte. Iena.

STRABO. 4,4 .

TACrTUS. Agricola, $I I$.

zIMMER, H. I894. Das Mutterrecht der Pikten. Zeitsch. f. Rechtsgeschichte, 15, 209-24O. 